\title{
WOOD DEBRIS IN RIVERS - ONE OF THE KEY FACTORS FOR MANAGEMENT OF THE FLOODPLAIN FOREST BIOTOPE OF EUROPEAN IMPORTANCE
}

\author{
MILOSLAV ŠINDLAR ${ }^{1}$, JIŘí LOHNISKÝ ${ }^{2}$, JAN ZAPLETAL $^{3}$, IVO MACHAR ${ }^{4}$ \\ 1, 2, 3 ŠINDLAR EU, s.r.o., Býšt', Czech Republic \\ ${ }^{4}$ Department of Biology, Faculty of Education, Palacky University Olomouc, Czech \\ Republic
}

Received: $23^{\text {rd }}$ June 2009 , Accepted: $10^{\text {th }}$ February 2010

\begin{abstract}
The article deals with analysis and management of wood debris accumulation in the Morava River within the Special Area of Conservation Litovelske Pomoravi (Czech Republic). Wood debris creates interference of interests between nature conservation (requirements for keeping wood debris in the stream) and foresters as well as water managers (requirements for removing wood debris from the flow area of the river). Based on the presented analyses, there was a set of wood debris management measures proposed in Litovelske Pomoravi in order to respect dynamics of fluvial succession series of floodplain forest biotopes, which are included in the Natura 2000 system.
\end{abstract}

Keywords: Floodplain biotopes, forest management, lowland river, Natura 2000, wood debris.

\section{INTRODUCTION}

An increasing number of scientific papers have been addressing the problems of wood debris in watercourses since the seventies (HYNES 1970; WILLIAMS 1987). Wood debris has been studied in terms of its influence over the geomorphologic development of fluvial ecosystems (ABBE, MONTGOMERY 1996; BOON et al. 1992; MONTGOMERY, BUFFINGTON 1998; ROSGEN 1996) as well as in terms of important ecological functions, e.g. wildlife habitat formation (COWX, WELCOMME 1998; WARD 1998; WARD et al. 1999). Wood debris also affects significantly the fluvial processes in watercourses, mainly the bed-load regime, the changes of stability of the river basin and the frequency of occurrence of shallow sections with pools (LEOPOLD et al. 1964). A great attention is therefore being given to the conservation management of wood debris (MAITLAND, MORGAN 1997; MONTGOMERY 1997; GERHARD, REICH 2000).

On the present, there has been a network of conservation areas known as Natura 2000 (by Habitat Directive, see LÉVÊQUE, MOUNOLOU 2004) being created in the Czech Republic (ROTH 2003) containing habitat types of European importance. Optimum management models are being sought (Composite Authors 2006) for maintenance of those biotopes in favourable conditions from the conservation point of view (EUROPEAN COMMISSION 2000). Ones of the problematic biotopes in terms of suitable management are azonal floodplain forest communities (KLIMO et al. 2008). 
The maintenance of certain kinds of floodplain habitats - mainly the fore phases of floodplain forest on new-laid alluvial deposits and the so called "softwood alluvial forest" depends on the functioning of dynamic progress of fluvial success series of alluvial biotopes (BUČEK, LACINA 1994).

The aim of this article is to prove on the base of unpublished data from Litovelske Pomoravi (ŠINDLAR et al. 2003) that problems of wood debris can be one of the key factors determining the principles of floodplain management.

\section{MATERIAL AND METHODS}

\section{$\underline{\text { Study area }}$}

Problems of wood debris were studied on the Morava River in the Litovelske Pomoravi Protected Landscape Area (PLA) in the Czech Republic. The area of study within the Morava River was demarcated from the 273.0 river kilometre (the railway bridge in Moravicany) to the 242.5 river kilometre (the road bridge in Chomoutov) - see Fig. 1 .

The ramose stream network of the Morava River creates a unique fluvial system in Litovelske Pomoravi. The recognized kind of anastomous river system in Litovelske Pomoravi originated and is being formed under specific natural circumstances that have been modified by human activity to a great extent (KIRCHNER, IVAN 1999).

The flood-plain forest habitats, imminently following the meandering Morava River, have also been intensively anthropogenic influenced (HOŠEK 1987). The floodplain forest habitats, important from the Natura 2000 network point of view, create an ecological phenomenon known as the fluvial succession series of floodplain forest biotopes (BUCEKK, LACINA 1994). This was described in detail in the paper by MACHAR 2008a. The occurrence and condition of floodplain forest habitats led to the registration of Litovelske Pomoravi into the network of conservation areas of European importance known as Natura 2000 with the statute of locality of European importance - Special Area of Conservation (SAC, for definition of SAC see MIKO et al. 2005). The floodplain forest habitats are subjects of conservation as the SAC Litovelske Pomoravi which means that the aim of conservation of SAC within the Natura 2000 network is to maintain the floodplain habitats in condition favourable from the conservation point of view and for reaching that aim it is necessary to set an appropriate area management (EUROPEAN COMMUNITIES 2003).

\section{Methods}

The field survey of wood debris within the area of study was carried out at the time of low flow in the Morava River from August to September 2003 (ŠINDLAR et al. 2003). During the field survey the localization of wood mass accumulation in the river was recorded as well as the direction orientation of logs (according to the cardinal points). A part of the field survey was a detailed photographic documentation (authors: BURES and MACHAR). Data gathered in field were transformed into resulting graphic outputs in ratio scale 1:10 000. The wood debris types detected in field were classified according to (ABBE, MONTGOMERY 2003). This classification refers to wood debris type of "large wood debris" (LWD) defined as wood mass with the diameter of over $10 \mathrm{cms}$ and the length of over $2 \mathrm{~m}$ (FOX 2002, KRAFT et al. 2002). The division of the study segment into categories was based on occurrence and frequency of a particular accumulation of wood debris with regard to the knowledge on anthropogenic influence of the geomorphologic development of the Morava River within the area of study (KIRCHNER et al. 1999; MÁČKA 2000). 
Fig.1: Litovelske Pomoravi: the layout of SAC Litovelske Pomoravi in the Czech Republic; delimitation of the area of study on the Morava River (arrows); categorization of the Morava River according to occurrence and frequency of wood debris in the river (sections marked I, II, III). Orig.

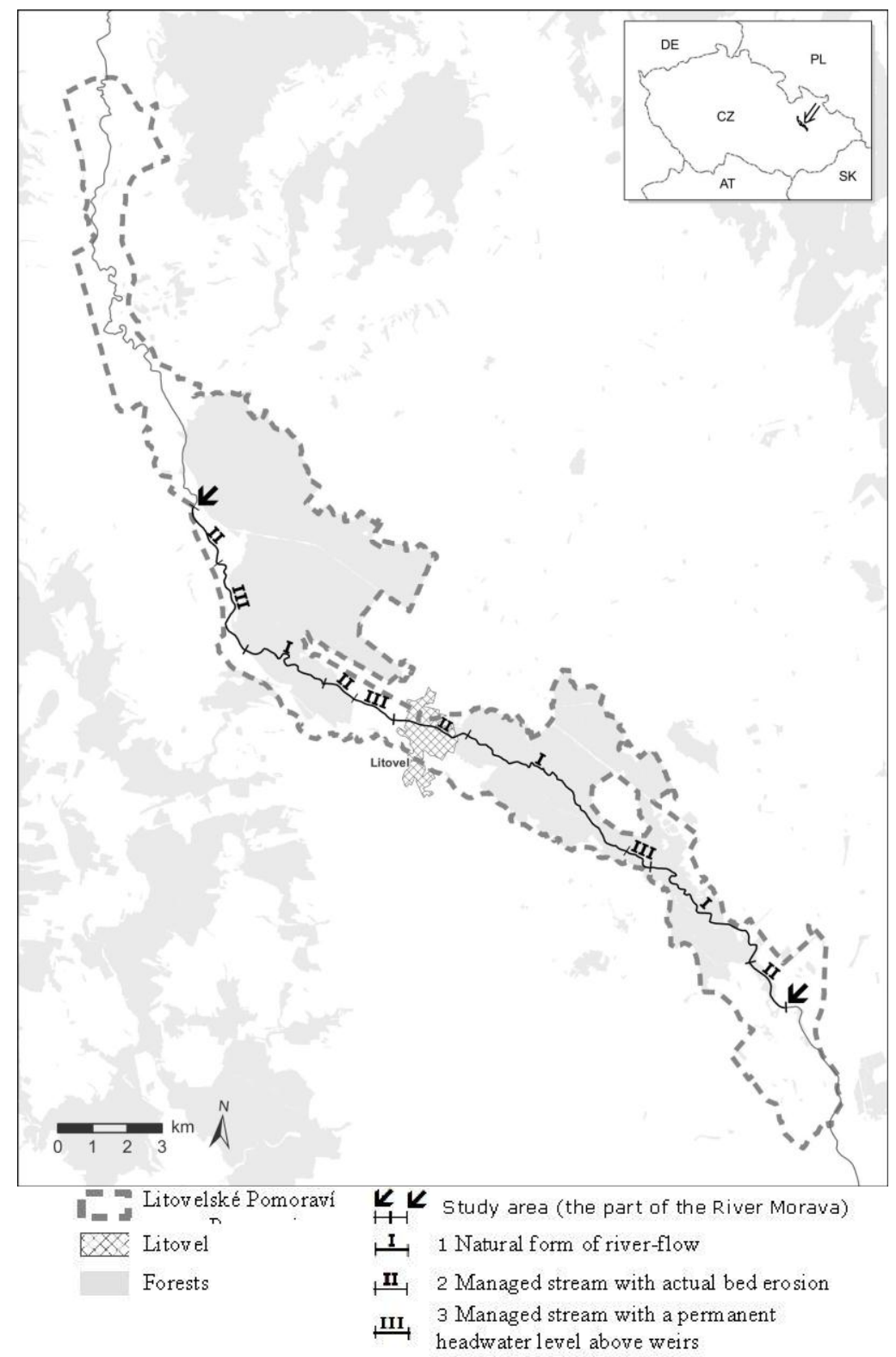

The aim of the proposed measures and principles of a differentiation management of wood debris in Litovelske Pomoravi is to create conditions for sustainable maintenance of dynamic development of fluvial succession series of floodplain forest biotopes. Dynamics 
of fluvial processes should enable continuous formation and succession development of river gravel banks biotopes, muddy river banks biotopes and fore succession phase of floodplain forest, mainly the group of forest types of Saliceta albae sup. and Saliceta fragilis inf. that belong among the most ecologically valuable and also the rarest types of softwood alluvial forests in the Czech Republic (BUČEK, LACINA 1999). The draft of management measures of wood debris in the river was created considering the expected impact of wood debris on the subject of conservation - the SAC Litovelske Pomoravi defined above. Results of this study were incorporated into the proposed Management Plan of Litovelske Pomoravi PLA (MACHAR et al. 2004).

\section{RESULTS}

\section{Classification of wood debris types in the Morava River}

\section{Wood debris of autochthonous origin}

This kind of wood debris composes mainly of large (fully grown) trees the height of which reaches or overreaches the width of the river basin and that are fallen in the place of their original growth. These trees were blown down to the river usually in the erosion (scour) section of the riverside which could be caused by the natural erosion of the riverside.

The trees fallen in the river relatively recently (i.e. the trees that have not yet been shifted by a large flood) are usually positioned vertically across the stream and the treetops lie on the opposite riverside contrary to the root balls. Those trees act - from the ecological point of view - as so called "key members" (ABBE, MONTGOMERY 2003), because more and more debris gets caught on them resulting in accumulation of debris, i.e. obstruction of the stream with a huge importance for fluvial processes and dynamics of the fluvial succession series of river biotopes (Fig.2). The trees lying in the river relatively on a long term basis (i.e. for at least several years and after at least one significant flood in the river basin) are usually shifted into a crossways position or lie in parallel with the stream direction.

\section{Wood debris of allochthonous or combined origin}

This category covers mainly smaller trees with the height falling short of the width of the river basin. Those trees lie generally in parallel with the stream direction. The size, shape and position of those trees in the stream influence the down-stream transport (Fig.3). Those trees are usually caught by "key members" during their down-stream locomotion creating so called combined debris. If allochthonous debris transported through the river basin gets caught on gravel-sand alluvium sediments, it creates so called "bar apex jams" that can be stabilized and gradually "buried" in the river basin under more gravel-sand sediments (Fig.4). 
Fig. 2: Obstruction (wood debris of combined origin) with a large ecological importance for the flood-plain forest ecosystem (the Morava River, Litovelske Pomoravi)

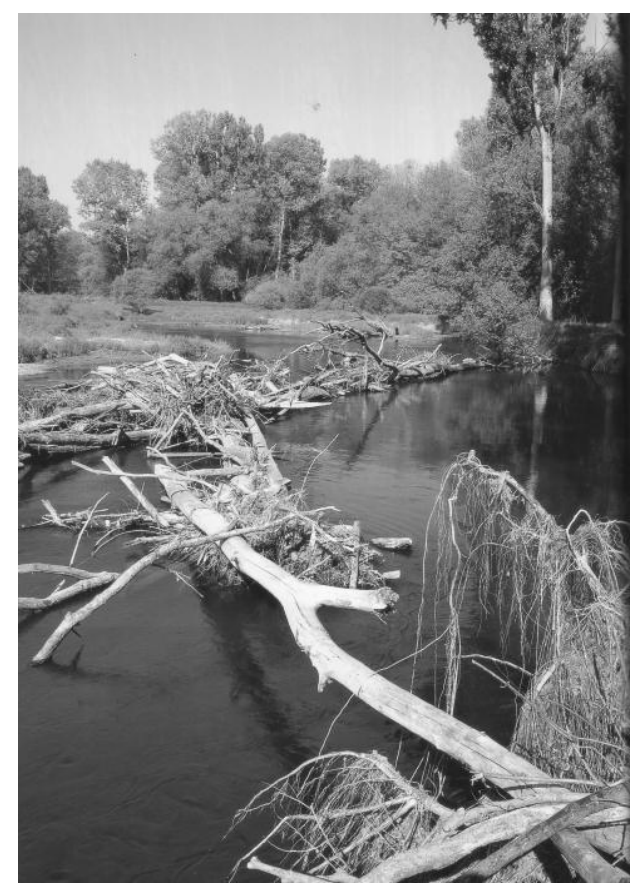

Fig. 3: Wood debris of allochthonous origin (the Morava River, Litovelske Pomoravi)

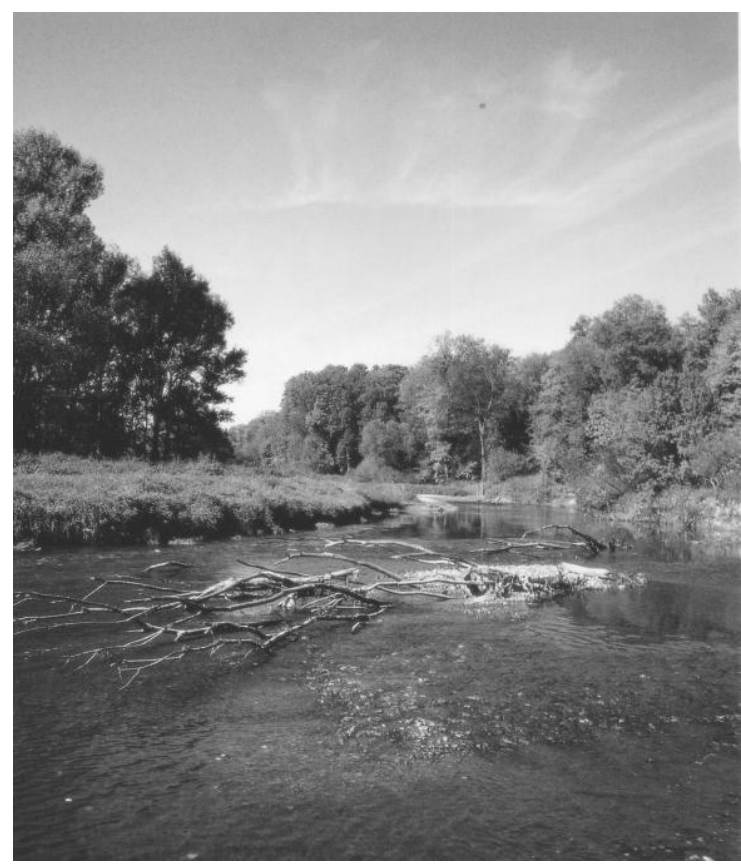


Fig. 4: Burial of allochthonous debris in bar apex jams (the Morava River, Litovelske Pomoravi)

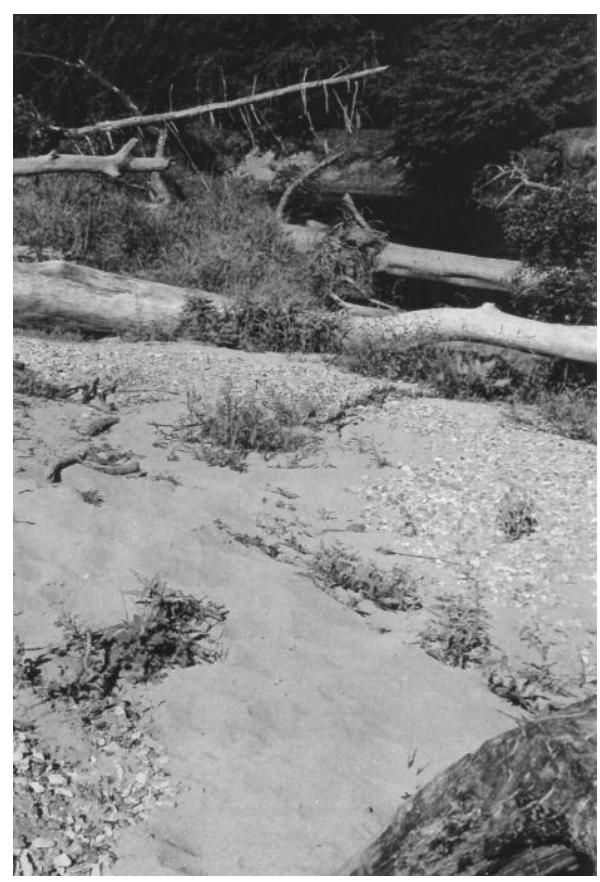

Categories of the Morava River sections based on the occurrence and frequency of wood debris and the influence of wood debris over biotopes

Within the area of study there were three categories of the Morava River defined:

I. Natural form of river-flow with a large number of debris accumulations within the river basin (sections marked with figure I on the map Fig.1)

The meandering river basin in state of nature, with actual fluvial (river basin forming) processes, and with river banks of different kinds. In this kind of river basin of the Morava River we found the greatest variability of types, percentage occurrence, and frequency of wood debris presence (Fig.5). The influence of debris on fluvial processes in this category is significant; some debris accumulations essentially influence the geomorphologic development of the river and its floodplain within the area of study: e.g. the debris accumulation in area of Velky ostrov (by Litovel) which led to the debacle of a meander neck, transfer of the river basin, and creation of new softwood alluvial forest (= willowpoplar forest of lowland rivers) biotopes on the meander of the former river basin within the area of ca. 2 ha in 1990 (MÁČKA 2000, Fig.6). Debris caught on river banks supports sedimentation of gravel-sand as well as fine floating solids and formation of river gravel banks and muddy river banks biotope types (CHYTRÝ et al. 2001) - see Fig.7. 
Fig. 5: Relative distribution of wood debris (\% of accumulations per $1 \mathrm{~km}$ of the river) in individual categories of the Morava River in Litovelske Pomoravi (categories I, II, III - see the article) (by ŠINDLAR et al. 2003)

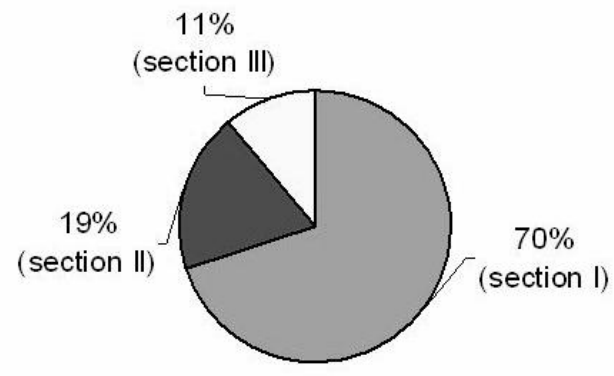

Fig. 6: New formed biotopes of soft flood-plain forest on the Morava River in Litovelske Pomoravi (locality Velky ostrov /Great Island/)

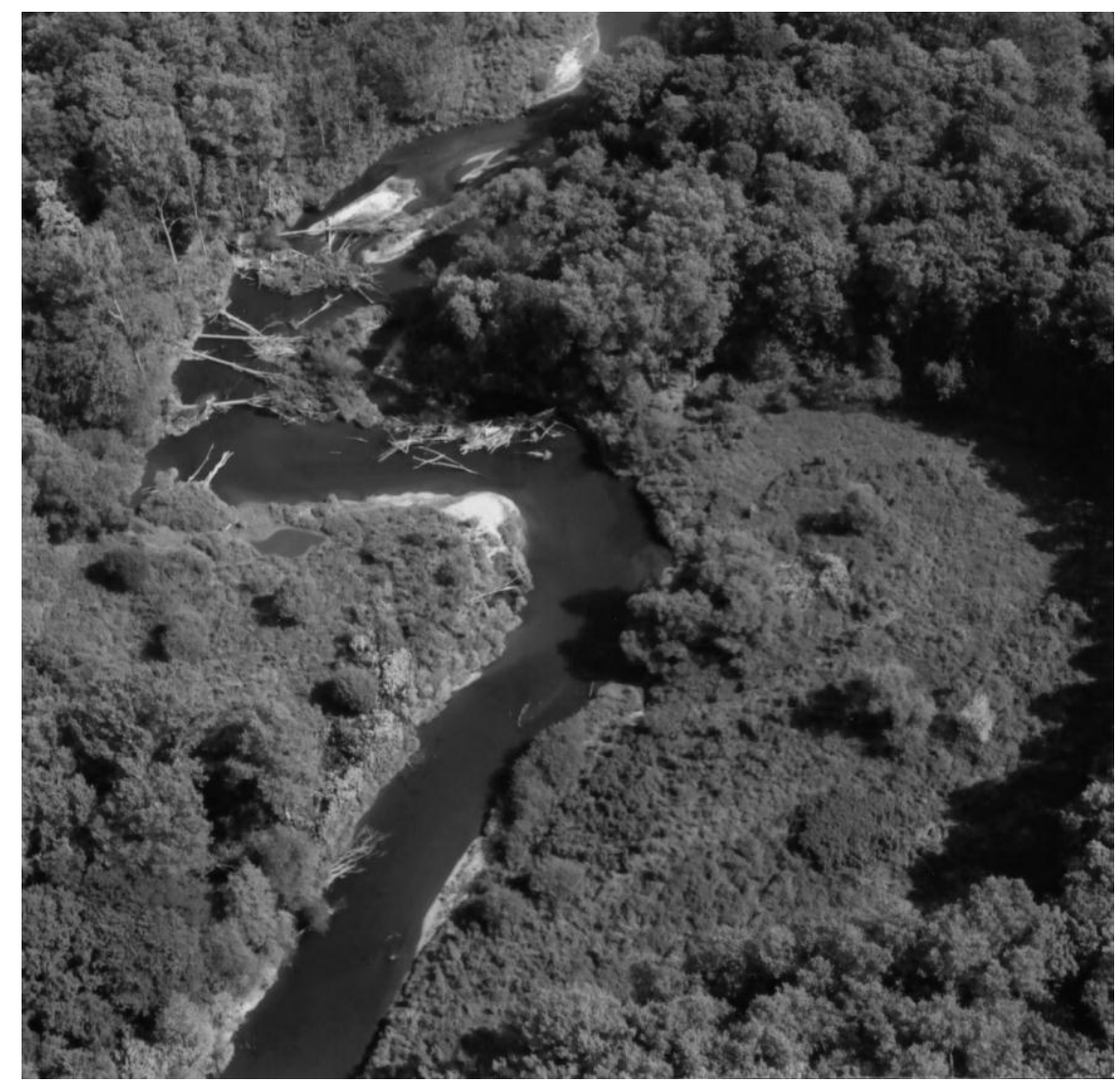




\section{Fig.7: Debris supports stabilization of alluviums and formation of biotopes}

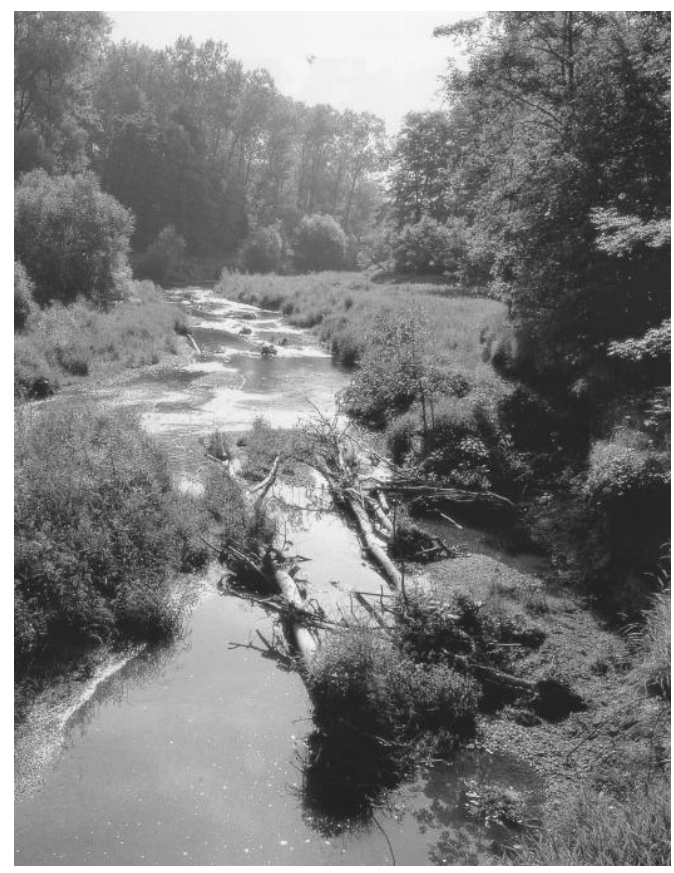

II. Managed stream with actual bed erosion and with medium occurrence of debris accumulation in the river basin (sections marked with figure II on the map Fig.1).

Wood debris in this category is usually directed crossways to the stream or lies in parallel with the stream direction. These sections of the stream are under a strong anthropogenic influence (the river basin has been technically straightened, the river banks technically stabilized) and therefore debris there diversifies rather uniform habitat conditions. Autochthonous debris doesn't usually (except for very rare occasions) exist there. The possibility of fixation and accumulation of allochthonous wood debris is very small in those sections; the amount of it is much smaller than in natural sections of the river (Fig.5). In places where the river stream slows down, mainly during dry-weather flow (predominantly in summer), can debris caught by the river bank help to form local river gravel banks biotopes and therefore support diversification of the habitat within the uniform surrounding.

III. Managed stream with a permanent headwater level above weirs with minimum amount of debris accumulation in the river basin (Fig.5).

The water flow is very slow and fluvial processes are highly restricted there (sections marked with figure III on the map Fig.1). The rarely fallen trees in the river are positioned crossways to the stream. Debris accumulation is not acceptable there due to the water management (proximity of water buildings - weirs), therefore trees fallen in the stream are immediately pulled out and taken away. The influence of debris on fluvial processes is rather small and in context of slow water flow it's restricted to the support of local formation of muddy river banks habitats. 
According to the results of wood debris mapping in Litovelske Pomoravi (Fig.5), there are major differences between individual categories of the stream in term of occurrence and frequency of wood debris accumulations. This is possible to account for the fact of different character of individual sections, the likelihood of formation of autochthonous debris, and the intensity of water management by water undertaking. The occurrence of debris accumulations in natural sections of the river enables their high level of nature conservation (through National Nature Reserves, see MACHAR et al. 2003) which doesn't allow the management to interfere with the development of the river.

There are two major amplitudes of debris accumulation abundance within the stream longitudinal section of the Morava River in Litovelske Pomoravi shown on Fig 8. The first amplitude on Fig. 8 in the $8^{\text {th }}$ kilometre of the studied section describes the natural section of the Morava River within the National Nature Reserve of Vrapac while the second outstanding amplitude between the 23rd and 28th kilometre describes the situation within the area of the National Nature Reserve Ramena reky Moravy/The Morava River Fleets/ in section under the weir by the village Hynkov.

Fig. 8: Number of debris accumulations in the Morava River in the stream longitudinal section of the whole area of study in Litovelske Pomoravi (by ŠINDLAR et al. 2003)

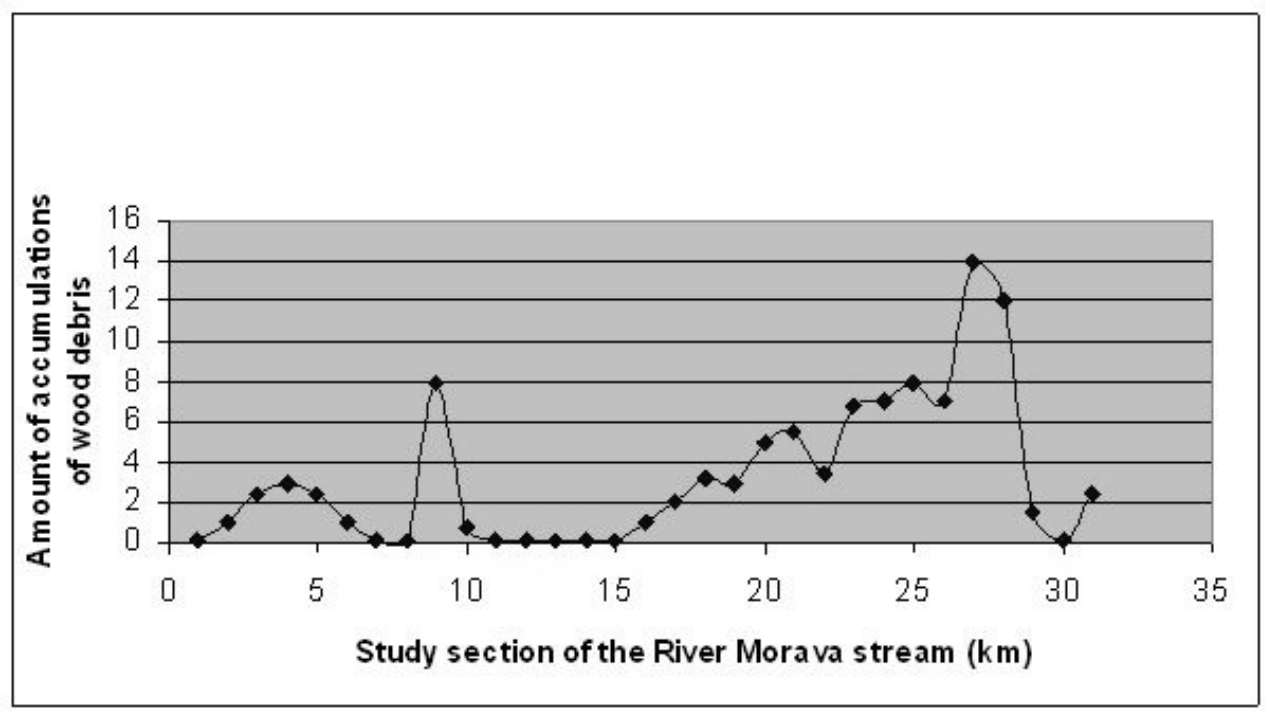

\section{Wood Debris Management Proposal}

Debris accumulation in the Morava River within the area of study often creates interference of interests between nature conservation on the one hand (requirements for keeping wood debris in the stream) and foresters as well as water managers on the other hand (requirements for removing wood debris from the flow area of the river).

Based on the above presented analyses, there was a set of wood debris management measures proposed in Litovelske Pomoravi (Tab 1.) in order to respect dynamics of fluvial succession series of floodplain forest biotopes and, at the same time, to allow water managers to ensure water management within exposed sections where wood debris could threaten water buildings (weirs). 
Table 1: Proposed measures of wood debris management in Litovelske Pomoravi

\begin{tabular}{|l|l|}
\hline Management measure & Subject of management measure \\
\hline Wood debris catchers & Catching wood debris carried by the river ahead \\
\hline $\begin{array}{l}\text { Stabilization of wood debris in } \\
\text { experimental locality of Vrapac }\end{array}$ & Anchorage of large wood debris in the river bank \\
\hline
\end{tabular}

Wood debris catchers were designed as simple equipment with the intention of catching the debris transported by the stream by the end of the sections of the Morava River classified as natural forms of river-flow with a large number of debris accumulations within the river basin (sections marked with figure II on the map Fig.1). The principle of the engineering solution of a wood debris catcher is shown on Fig.9. The catching of wood mass was realised by a wooden construction made up of individual components (wooden piles and beam structure) ice guard-like. The construction should be equipped with a gateoperating platform with railing. The wood caught on the piles is possible to withdraw by mechanisation from the operating space $\left(2,200 \mathrm{~m}^{2}\right)$ on the right river bank. Should the catcher get filled by debris, the flow area would be reduced. To avoid the increase of water level above the catcher and flooding the requisite flow will be transferred by a connected fleet on the left river bank. The flow fleet will be subject to a gradual earthing-up and it will be required to maintain the necessary flow area during operation. These catchers could be drawn up as a part of revitalization measures on the Morava River and their potential execution has been discussed by the update of the management plan for the Protected Landscape Area hearing.

Fig. 9: Scheme proposal of engineering solution of a wood debris catcher (driftwood trap) (by ŠINDLAR et al. 2003)

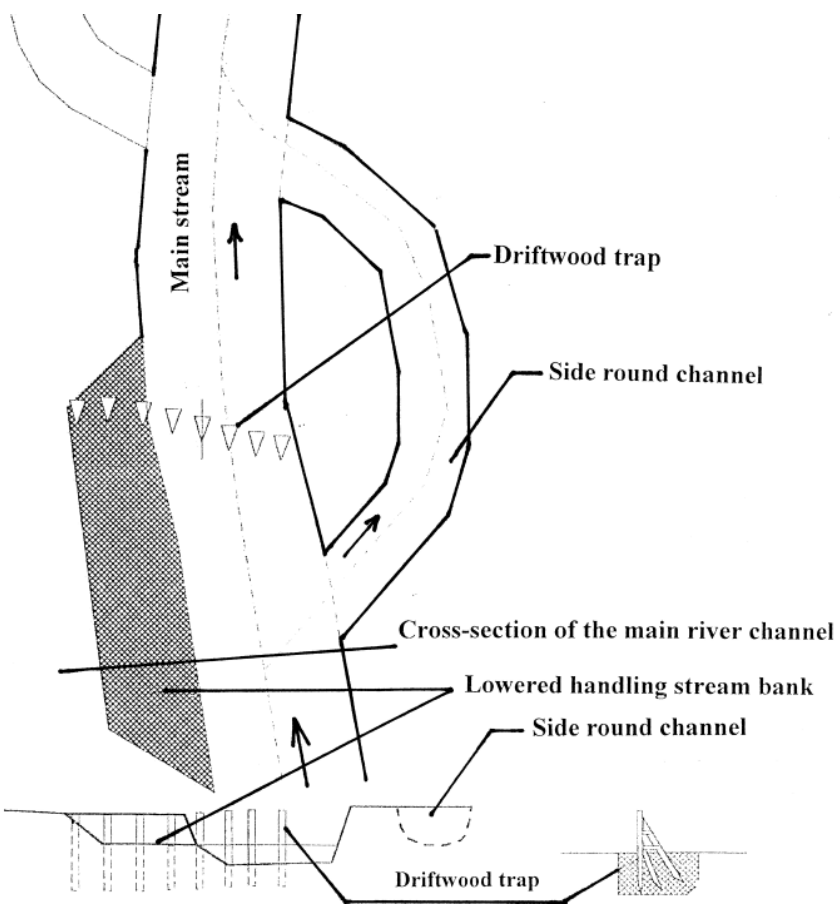


Debris stabilization in the experimental locality of Vrapac was trial-tested in winter 2003/2004. The main aim of the measure was to test possibilities of wood debris stabilization in a particular locality and the influence of the measure over a subsequent wood debris accumulation. The subsidiary aim of the field trial was to test the possibility of partial deceleration of headwater erosion front progress which takes place in this section of the river due to engineering control and straightening of the stream in the thirties (KIRCHNER et al. 1999). The attempt to slow down the headwater erosion process is based on presumption that gravel-sand transported by the river will settle on stabilized debris.

The actual realization of the measure consisted of stacking logs into a longitudinal construction and anchoring some logs onto the undercut-slope (erosion) bank of a meander with help of specialized device. The work was funded by the Protected Landscape Area of Litovelske Pomoravi Authority. The logs loosely accumulated on the river bank were directionally arranged by an excavator to put them in parallel way with the shore line. The whole construction was anchored to stumps on the shore by cable mooring. All trees were geodetically polarized (Fig.10) in order to creation of base of the future monitoring. The interpretation of the monitoring in 2008 proved that this construction was stable during the monitoring period and that wood debris accumulation caught on the construction increased 1.5 times during that period.

\section{Fig.10: Stabilization of wood debris in locality of Vrapac - layout after realization and geodetical survey (by ŠINDLAR et al. 2003)}

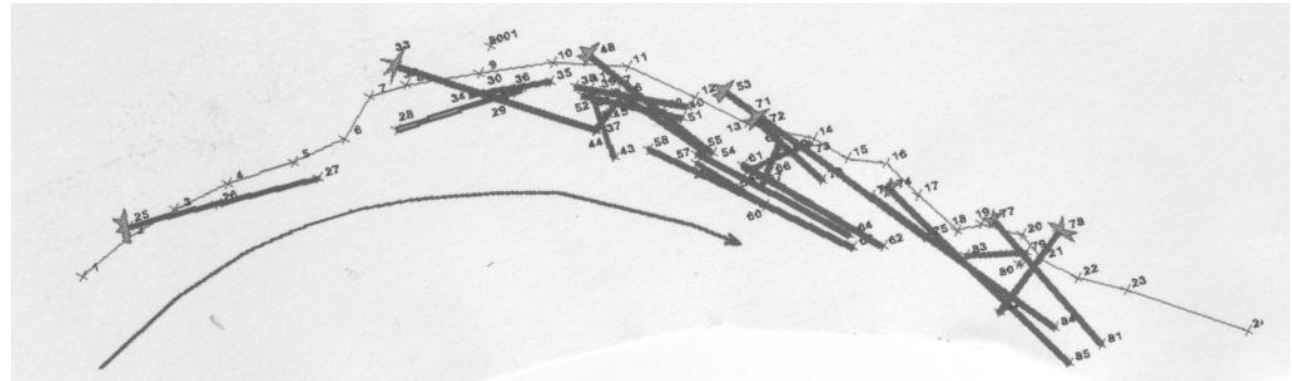

Potential impact of this measure on headwater erosion undergoing in the river basin will be possible to evaluate after a longer period of time (in the frame of decades) as a part of a future geomorphologic survey.

Based on the above accomplished categorization of the Morava River sections according to the occurrence and frequency of wood debris, there is a differentiation approach to wood debris management in Litovelske Pomoravi elaborated for the water management authority of the Morava River and for forestry management of riparian stands (Tab.2). 


\section{Table 2: Differentiation Approach to Wood Debris in Litovelske Pomoravi}

\begin{tabular}{|l|l|l|}
\hline $\begin{array}{l}\text { Section of the } \\
\text { Morava River }\end{array}$ & Management Type & Activities \\
\hline I. & Wood debris management & $\begin{array}{l}\text { Removal of wood debris from the watercourse } \\
\text { is prohibited }\end{array}$ \\
\hline II. & Wood debris management & $\begin{array}{l}\text { Removal of wood debris from the watercourse } \\
\text { is possible only if the occurrence of combined } \\
\text { wood debris (i.e. stream obstruction) is } \\
\text { imminent; preventively it is possible to remove } \\
\text { trees inclined over the stream and threatening } \\
\text { to fall in }\end{array}$ \\
\hline III. & Wood debris management & $\begin{array}{l}\text { Removal of wood debris from the watercourse } \\
\text { is carried out without any limitations }\end{array}$ \\
\hline I., II., III. & $\begin{array}{l}\text { Forest management of } \\
\text { riparian stands and } \\
\text { floodplain forests in } \\
\text { immediate contact with the } \\
\text { stream }\end{array}$ & $\begin{array}{l}\text { Selection management leading towards coppice } \\
\text { with standards }\end{array}$ \\
\hline I, II & $\begin{array}{l}\text { Forest management on } \\
\text { newly formed muddy and } \\
\text { gravel-sand deposits } \\
\text { formed by the meandering } \\
\text { river }\end{array}$ & $\begin{array}{l}\text { Newly formed alluviums are not artificially } \\
\text { afforested and are left to spontaneous } \\
\text { succession of flood-plain forest }\end{array}$ \\
\hline
\end{tabular}

Strict conservation of wood debris in the section of the river marked as type I (natural form of river flow) is motivated by conservation interests to maintain dynamics of natural fluvial processes supported by the presence of wood debris. In the managed and exposed section of the river (type III) wood debris removal is not being restricted. Forestry management of vegetation immediately following the stream leading towards formation of coppice with standards stand type seems to be the optimal solution for all above presented interests: it enables interference with riparian stands; it can contribute to formation of ecologically very valuable stands of pollard willows; and at the same time it ensures maintenance of large tree individuals valuable from the conservation point of view on the river bank.

\section{DISCUSSION AND CONCLUSION}

Wood debris management in rivers, especially the utilization of wood debris in revitalization of rivers, has been addressed by e.g. ABBE, MONTGOMERY (1996); EISELTOVÁ, BIGGS (1995); HILDEBRAND et al. (1998) and SHIELDS et al. (2004). ANGRADI et al. (2004) deal with these problems in the Missouri River (USA), DAHLSTRÖM, NILSSON (2004) in central Sweden and GURNELL (2001) in Italy.

Wood debris is considered to be an important component for ecosystem management of large rivers and their floodplains (GURNELL et al. 2000; HERING et al. 2000). KAIL (2003) deals with influence of large woody debris on the geomorphology of some central European rivers.

Attention has been paid to wood debris in mountain and piedmont gills so far in the Czech Republic, mainly from the forest-technical point of view of torrent control (HERYNEK 2004). Wood debris problems are recently arising as a new and important 
topic of nature conservation in the Czech Republic, especially in connection with the recurrence of flood control by near natural methods (e.g. KOŽENÝ, SIMON 2006; KOŽENÝ 2007; MÁČKA, KREJČÍ 2006) and revitalization of stream systems (e.g. GERGEL 1998; VLČEK, ŠINDLAR 2002; VRÁNA 2004).

There is a focus on wood debris as a habitat for fish communities in Litovelske Pomoravi (PEŇÁZ, JURAJDA 1993). The positive ecological impact of trees fallen into the watercourse over the natural purification capacity of the Morava River has been advised by ŠTĚRBA (1994).

The wood debris capacity to create a foraging and resting site for Common Kingfisher (Alcedo atthis) has been described in terms of the theory of hunting behaviour of birds by BUREŠ (1987). That is the reason why management of wood debris and riparian stands (that are source of trees fallen in the stream) is important for maintenance of Common Kingfisher population as a subject of conservation of the Special Protection Area in Litovelske Pomoravi in favourable conditions from the conservation point of view (MACHAR 2008b).

Wood debris has been described as a part of food source for European Beaver (Castor fiber) in Litovelske Pomoravi by LEHKÝ (1999). The population of European Beaver (Castor fiber) has been newly contributing to the formation of autochthonous debris in Litovelske Pomoravi since the re-introduction of the species in 1993. As indicated in e.g. GURNELL (1998), beaver plays a role of an "ecosystem engineer" in floodplain forest.

Problems of wood debris in connection with fluvial sediments regime in Litovelske Pomoravi were addressed for the first time already by the team of Institute of Geonics of the Academy of Sciences of the Czech Republic within the geomorphologic study of channel network of the Morava River (KIRCHNER et al. 1999; MÁČKA, KREJČÍ 2006). Anastomonous channel network of the Morava River within the Protected Landscape Area of Litovelske Pomoravi is characterized by clearly dominant meandering main stream of the Morava River while the rest of the connecting network of lateral periodical channels forms rather narrow river basins. The river basin of the Morava River is relatively stable and the meanders do not "shift" in the down-stream direction.

The influence of LWD on geomorphologic development of the river basin depending on the kind of debris and the longitudinal gradient of the river bed has been summarized by ABBE, MONTGOMERY (2003) and DANIELS, RHOADS (2003). The authors highlight the fundamental impact of "key members" over the development of meanders in lowland rivers ("key members" are large trees playing the role of "natural catchers" in debris accumulation). Results from Litovelske Pomoravi are comparable with data in that paper because even there KIRCHNER et al. (1999) consider great impact of vegetative debris accumulation on the geomorphology of the Morava River. It is also very probable that lateral periodical channels in Litovelske Pomoravi form exactly in places of barriers on the main stream (KREJČÍ 2000). Should this hypothesis be confirmed by following research, the ecological impact of debris for formation of fore succession phases of floodplain forest would be emphasized. The conditions of riparian and supporting stands have a great impact on the capacity of watercourses as bio-corridors in landscape (BÍNOVÁ 2006). The management method used for those stands has a significant influence over the formation of debris in the river. A number of authors (e.g. NEWBOLD et al. 1989) consider coppice management to be the optimal way for riparian stands. The forestry management recommendation on riparian stands included in this paper is in accordance with that generally accepted opinion.

The measure in locality of Vrapac (debris stabilization), present in this article, is probably the first experiment of this kind on a large lowland river in the Czech Republic. So far it is 
not possible to assess the influence of the measure over geomorphologic development of the river as for that a longer period of time in the frame of decades would be required. It is crucial to carry out monitoring of the measure in order to analyse it objectively.

Debris - mainly LWD and combined debris - has a large influence over fluvial processes (VAJNER, SIMON 2005) that further influence the condition and development of floodplain forest biotopes (BUČEK 1979).

Virtually no attention has been paid to debris management from the conservation of biotopes within the Natura 2000 network point of view in the Czech Republic (ANONYMUS 2006). As proved by KOŽENÝ, SIMON (2008) a safe management of wood debris in the rivers in the Czech Republic (with respect of ecological capacity of rivers) is feasible provided the differentiation management approach will be used. The wood debris management proposal in Litovelske Pomoravi introduced in this article is in accordance with the latter presented opinion.

\section{ACKNOWLEDGMENT}

This article has been elaborated thanks to the support of the research grant of the Ministry of Environment No. VaV 610/10/00: The Influence of Economic Impacts over Biodiversity Changes within the Areas of Special Protection, part: Issues of wood debris in the Litovelské Pomoraví Protected Landscape Area.

\section{REFERENCES}

Anonymus (2006). Pravidla hospodaření pro typy lesních přírodních stanovišt' v evropsky významných lokalitách soustavy Natura 2000. Výsledek jednání pracovní skupiny. Planeta, odborný časopis pro životni prostředí, XIV, 9/2006: 3-40.

Abbe, T.B., Montgomery, D.R. (1996). Large woody debris jams, channel hydraulics and habitat formation in large rivers. Regulated Rivers: Research and Management, 12: 210221.

Abbe, T.B., Montgomery, D.R. (2003). Patterns and processes of wood debris accumulation in the Queets river basin, Washington. Geomorphology, 51: 81-107.

Angradi, T.R., Schweiger, E.W., Bolgrien, D.W., Ismert, P. \& Selle, T. (2004). Bank stabilization, riparian land use and the distribution of large woody debris in a regulated reach of the Upper Missouri River, North Dakota, USA. River Research and Applications, 20: 829-846.

Bínová, L. (2006). Břehové a doprovodné porosty vodních toků s funkcí biokoridoru nebo biocentra ÚSES. In: Petrová, A., Ed., ÚSES - zelená páteř krajiny. 55-59 pp. Sborník př́spěvků ze semináře. Agentura ochrany př́rody a krajiny ČR, Česká společnost pro ekologii krajiny, Nadační fond prof.A.Bayera a Mendelova zemědělská a lesnická univerzita Brno.

Boon, P.J., Calow, P. \& Petts, G.E.(1992). River Conservation and Management. New York, John Willey and Sons Ltd.: 340 pp.

Buček, A. (1979). Problematika a význam ochrany geobiocenóz údolních niv. Zprávy Geografického ústavu ČSAV Brno, 15(5-6): 126-131. 
Buček A., Lacina J. (1994). Biogeografické poměry. Vybrané fyzickogeografické aspekty pro revitalizaci nivy Dyje v úseku VD Nové Mlýny - soutok s Moravou. Brno, Ústav geoniky AV ČR: 46-98 p.

Buček, A., Lacina, J. (1999). Geobiocenologie II. Brno, Mendelova zemědělská a lesnická univerzita: 249.

Bureš, S. (1987). Současné změny v krajině působící na ptactvo říčních toků. In: Sitko J., Trpák P., Eds., Vodní ptáci. 29-33 pp. Praha, Státní ústav památkové péče a ochrany prírody

Cowx, I.G., Welcomme, R.L. (1998). Rehabilitation of rivers for fish. Fishing New Books. Oxford, Osney Mead: 260.

Dahlström, N., Nilsson, C. (2004). Influence of woody debris on channel structure in old growth and managed forest streams in central Sweden. Environmental Management, 33: 376-384.

Daniels, M.D., Rhoads, B.L. (2003). Influence of a large woody debris obstruction on three-dimensional flow structure in a meander bend. Geomorphology, 51: 159-173.

Eiseltová, M., Biggs, J. (1995). Restoration of Stream Ecosytems, an itegrated catchment approach. Slimbridge: International Waterfowl and Wetlands Research Bureau: 170 pp.

European Commission (2000). Péče o lokality soustavy Natura 2000. Planeta, IX (4): 3-28.

European Communities (2003). Natura 2000 and Forests: Challenges and Opportunities. Brussels, European Union: 64 p.

Fox, M. (2002). Large woody debris: how much is enough? Seattle, Center for streamside studies, University of Washinhton: 22.

Gergel, J. (1998). Faktory pro oživení biotopu koryta upravených toků. Závěrečná zpráva projektu GAČR 526/96/1040. Praha, Výzkumný ústav meliorací a ochrany půdy: 31 p.

Gerhard, M., Reich, M. (2000). Restoration of streams with large wood: Effects of accumulated and built-in wood on channel morphology, habitat diversity and aquatic fauna. International Review of Hydrobiology, 85: 123-137.

Gurnell, A.M. (1998). The hydrogeomorphological effects of beaver dam-building activity. Progress Physics Geography, 22: 167-189.

Gurnell, A.M., Petts, G.E., Hannah, D.M., Smith, B.P.G., Edwards, P.J., Kollmann, J., Tockner, K. \& Ward, J.V. (2000). Wood storage within the active zone of a large European gravel-bed river. Geomorphology, 34: 55-72.

Gurnell, A.M., Petts, G.E., Hannah, D.M., Smith, B.P.G., Edwards, P.J., Kollmann, J., Ward, J.V. \& Tockner, K. (2001). Riparian vegetation and island formation along the gravel-bed Fiume Tagliamento, Italy. Earth Surface Processes and Landforms, 26: 31-62.

Hering, D., Kail, J., Eckert, S., Gerhard, M., Meyer, E.I., Mutz, M., Reich, M. \& Weiss, I. (2000). Coarse woody debris quantity and distribution in Central European streams. International Review of Hydrobiology, 85: 5-23.

Hildebrand, R.H., Lemly, A.D., Dolloff, C.A. \& Harpster, K.L. (1998). Design considerations for large woody debris placement in stream enhancement projects. North American Journal of Fisheries Management, 18: 161-167.

Hošek, E. (1987). Lužní lesy Litovelského Pomoraví pohledem historie. In: Šimek, P. (Ed.), Údolní niva, lužni lesy a návrh chráněné krajinné oblasti Litovelské Pomoraví. 61-85 pp. Sborník referátů. Olomouc, Okresní středisko památkové péče a ochrany prrírody 
Herynek, J. (2004). Historie hrazení bystřin v lesích v zemích českých a současný stav. Postavení hrazení bystřin v protierozní a protipovodňové ochraně lesa a krajiny, sborník referátů z konference, Hejnice v Jizerských horách. Praha, Česká lesnická společnost: 5-10.

Hynes, H.B.N. (1970). The Ecology of Running Waters. Toronto, University of Toronto Press: 555.

Chytrý, M., Kučera, T. \& Kočí, M., (2001). Katalog biotopů České republiky. Praha, Agentura ochrany př́rody a krajiny ČR: 304.

Kail, J. (2003). Influence of large woody debris on the morphology of six central European streams. Geomorphology, 51: 207-223.

Kirchner, K., Ivan, A. (1999). Anastomózni ríčni systém v CHKO Litovelské Pomoraví. Geologické výzkumy na Moravě a ve Slezsku v roce 1998, časopis ČAV Brno, VI: 19-20.

Kirchner, K., Ivan, A., Lacina, J., Máčka, Z., Hrádek, M., Hofírková, M., Petrová, A., Jurajda, P., Krejčí, M. \& Roštínský, P. (1999). Studium a modelování antropogenního ovlivnění ř́ční sitě v Národní prírodní rezervaci Vrapač (CHKO Litovelské Pomoraví). Studie Ústavu geoniky ČAV. Praha, MŽP ČR: 145+př́loha na CD ROM.

Klimo, E., Hager, H., Matič, S., Anič, I. \& Kulhavý, J. (2008). Floodplain Forests of the Temperate Zone of Europe. Kostelec nad Černými lesy, Lesnická práce: 623 p.

Kožený, P. (2007). Vliv desetileté povodně na transport dřevní hmoty uložené v korytě a nivě řeky Blanice. In: Měkotová, J., Štěrba, A O., Eds., Řični krajina 6. 107-112 pp. Sborník příspěvků z konference. Olomouc, Univerzita Palackého:

Kožený, P., Simon, O. (2006). Analýza naplavené dřevní hmoty na nádrži Znojmo po jarní povodni 2006. In: Měkotová, J., Štěrba, O., Eds., Řiční krajina 5. 111-118 pp. Sborník příspěvků z konference. Olomouc, Univerzita Palackého:

Kožený, P., Simon, O. (2008). Mrtvé dřevo ve vodních tocích - čas změnit zákony? In: Tuf, I.H., Kostkan, V., Eds., Výzkum v ochraně prírody. 14-15 p. Sborník z konference 9.12.9.2008 v Olomouci, Olomouc, Univerzita Palackého

Kraft, C.E., Schneider, R.L. \& Warren, D.R. (2002). Ice storm impacts on woody debris and debris dam formation in northeast U.S. streams. Canadian Journal of Fisheries and Aquatic Sciences, 59: 1677-1684.

Krejčí, M. (2000). Revitalizace lužních lesů v CHKO Litovelské Pomoraví s přihlédnutím k anastomóznímu říčnímu systému. In: Kovařík, P., Machar, I., Eds., Mokřady 2000. 87103 pp. Sborník z konference 13.-15.9.2000. Olomouc, Český Ramsarský výbor a MŽP Praha.

Lehký, J. (1999). Potravni ekologie bobra evropského (Castor fiber) v Litovelském Pomoraví. Diplomová práce. Olomouc, Univerzita Palackého: 134.

Lévêque, CH., Mounolou, J-C. (2004). Biodiversity. John Willey \& Sons, Hoboken.

Leopold, L.B., Wolman, M.G. \& Miller, J.P. (1964). Fluvial processes in geomorphology. San Francisco, W.H.Freeman and Company: 215.

Machar, I. (2003). Chráněná území CHKO Litovelské Pomoraví. In: Šafář J. et al., Chráněná území ĆR - Olomoucko, 1-60 pp. Svazek VI. Praha, Agentura ochrany prírody a krajiny ČR a EkoCentrum Brno.

Machar, I. (2004). Návrh aktualizace plánu péče o CHKO Litovelské Pomoraví. Nepublikovaný material, Správa ochrany př́rody, Praha. 
Machar, I. (2008a). Floodplain forests of Litovelské Pomoraví and their management. Journal of Forest Science, 54: 355-369.

Machar, I. (2008b). Ledňáček říční (Alcedo atthis) v Litovelském Pomoraví. Ochrana přirody, 6: 8-10.

Maitland, P.S., Morgan, N.C. (1997). Conservation Management of Freshwater Habitats Lakes, Rivers and Wetlands. London, Chapman \& Hall: 370.

Máčka, Z. (2000). Studium a hodnocení vývoje řiční sítě v Národni přirodní rezervaci Ramena reky Moravy. Studie. Brno, Ústav geoniky ČAV: 82.

Miko, L., Borovičková, H., Havelková, S., Roth, P., Stloukal, P. \& Vopálková, A. (2005). Zákon o ochraně prírody a krajiny: komentár. Praha, C.H.Beck: 526.

Máčka, Z., Krejčí, L. (2006). Plavená dřevní hmota (spláví) v korytech vodních toků - případová studie z CHKO Litovelské Pomoraví. In: Měkotová, J., Štěrba, O., Eds., Říčni krajina 4.10 p. Sborník príspěvků z konference, Olomouc.

Montgomery, D.R. (1997). What's best on the banks? Nature, 388: 328-329.

Montgomery, D.R., Buffington, J.M. (1998). Channel processes, classification and response potential. In. Naiman, R.J., Bilby, R.E., Eds., River Ecology and Management. 13-42 pp. New York, Springer-Verlag

Newbold, C., Honnor, J. \& Buckley, K. (1989). Nature Conservation and the management of drainage channels. Sandy, Lincoln, NCC/ADA: 320.

Peňáz, M., Jurajda, P. (1993). Fish assemblages of the Morava River: Longitudinal Zonation and Protection. Folia Zoologica, 42 (4): 317-328.

Rosgen, D.L.A. (1994). Classification of natural rivers. Catena, 22: 69-199.

Rosgen, D.L.A. (1996). Applied river morphology. Colorado Pagosa Springs: 298.

Roth, P. (2003). Legislativa Evropských společenství v oblasti územni a druhové ochrany prírody. Praha, Ministerstvo životního prostředí: 181.

Shields, F.D., Morin, N. \& Cooper, C.M. (2004). Large woody debris structures for sand-bed channels. Journal of Hydraulic Engineering, 130: 208-217.

Šindlar, M., Zapletal, J. \& Lohniský, J. (2003): Problematika plavené dřevni hmoty (spláví) $v$ CHKO Litovelské Pomoraví. Nepublikovaná studie pro agenturu ochrany př́rody a krajiny ČR, Praha.

Štěrba, O. (1994). Přirodni hodnoty a stupeň odpřirodněni moravských řek. Průběžná zpráva za rok 1993, Projekt Morava. Olomouc, Univerzita Palackého: 11.

Vajner, P., Simon, O. (2005). Mrtvé dřevo jako stabilizující faktor v nivách potoků, nebo překážka v korytě? In: Měkotová, J., Štěrba, O., Eds., Řični krajina 3. 368-377 pp. Sborník př́spěvků z konference. Olomouc, Univerzita Palackého.

Vlček, L., Šindlar, M. (2002). Geomorfologické typy vodních toků a jejich využití pro revitalizace. Vodni hospodárství, 6: 172-176.

Vrána, K. (2004). Revitalizace malých vodnich toků - součást péče o krajinu. Praha, Consult: 60 .

Waed, J.V. (1998). Riverine landscapes: biodiversity patterns, disturbance regimes and aquatic conservation. Biological Conservation, 83: 269-278.

Ward, J.V., Malard, F. \& Tockner, K. (1999). Landscape ecology integrates pattern and process in river corridors. In: Wiens, J.A., Moss, M.R., Eds., Issues in Landscape Ecology. Proceedings from Fifth World Congress of International Association for Landscape Ecology, 97-102 pp. Colorado State University.

Williams, G.P. (1987). River meanders and channel size. Journal of Hydrology, 88: 147-164. 